FGORES OF TERTIARY FOSSILS FROM TAPLE CAPE TASILANIA.

No. I. - Torebra simplex

II. - Voluta Weldii

III.-Natica Wintlei

IV.— polita

V.-Typhis MLCoyi

VI.-Fusus Meredithia

V1I._- Roblini

VIII.-Tritton Albotti

IX.-Cyprea Archeri

X. - Vemis Allporti

XI.-Crassatella oblongu

XII._-_._. aphrodina

XIII.-Lyonsia Agnewi

XIV.-Solecurtus Legrandi
(Woods)

,

,

"

"

"

"s

,

9

9

,

;

s)

;9 

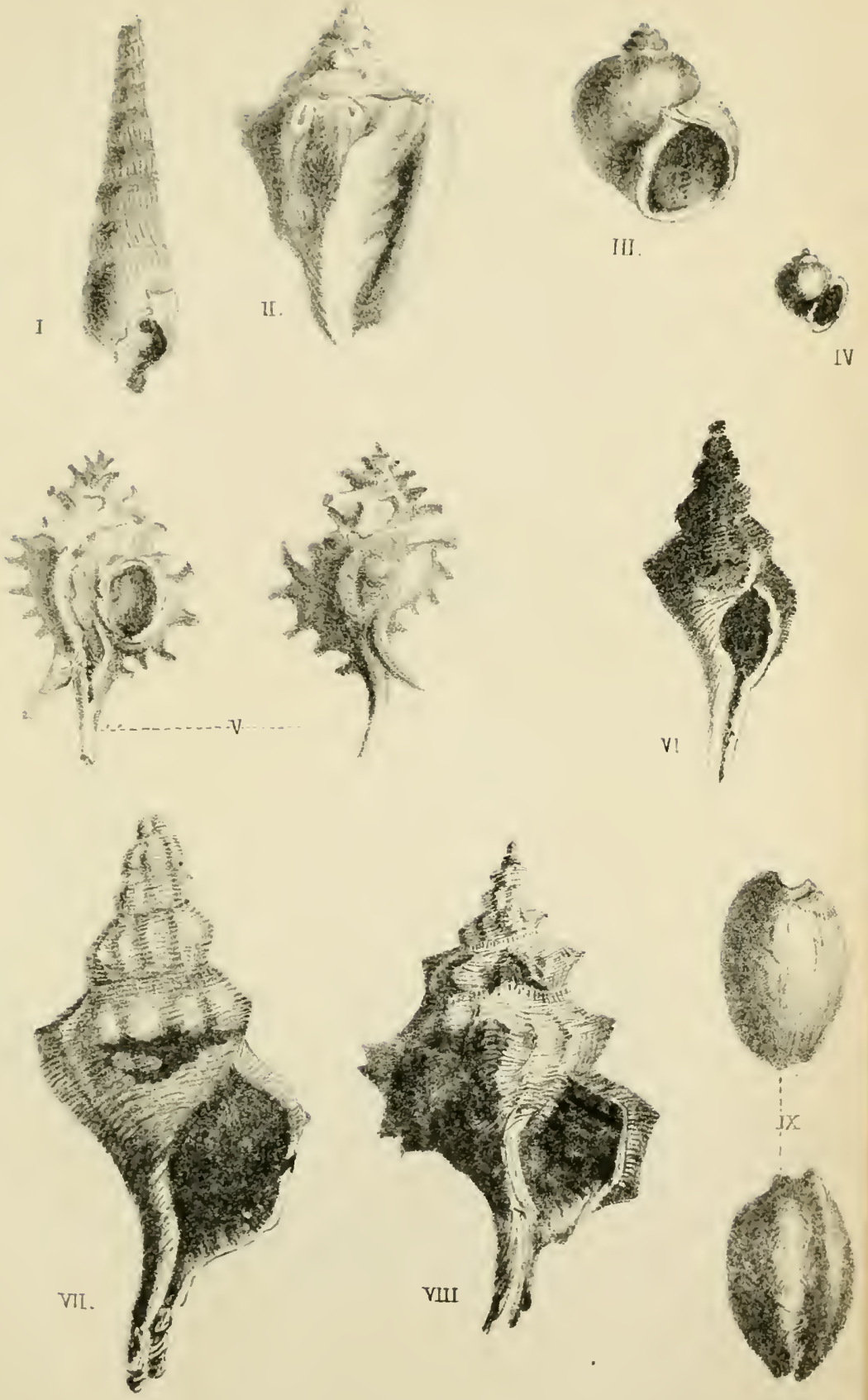


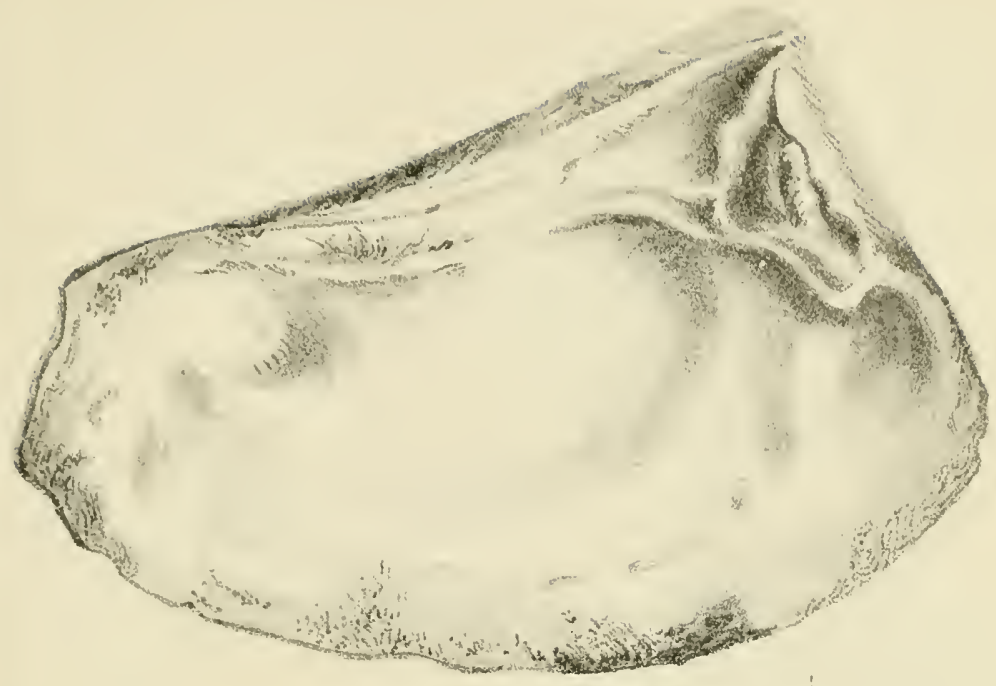

$X I$.

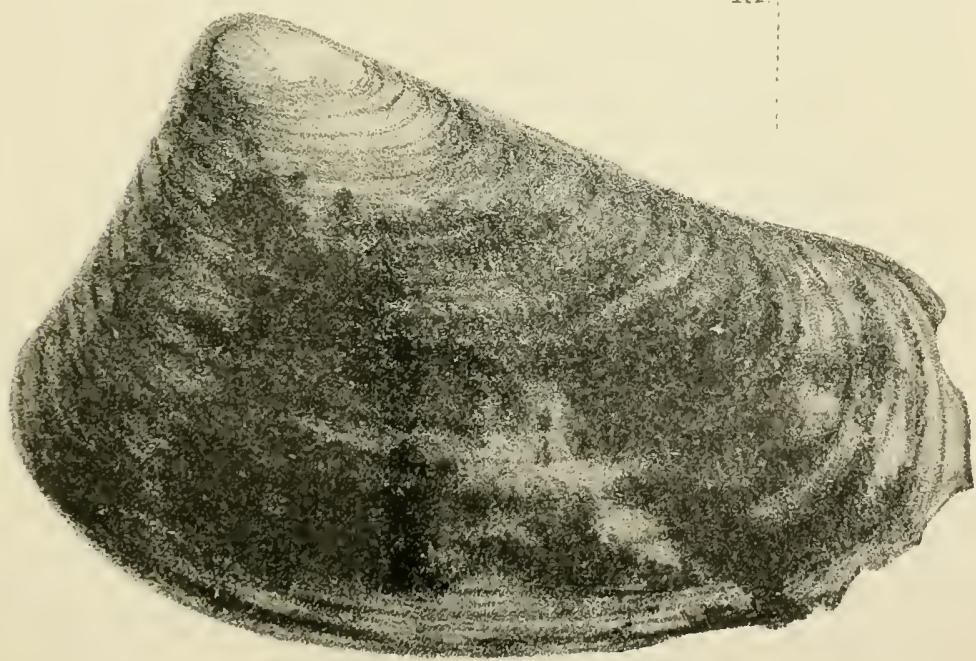




\section{ON SOME TERTIARY FOSSILS FROM TABLE CAPE.}

By тue Rev. J. E. Tenison Woods, F.L.S., F.G.S., \&c.

\section{[Read 9th March, 1873.]}

My attention has been called to some fossils in the Museum of the Society, which are alleged to have been collected close to the sea-side at Tablo Cape. They were presented to the Soeiety by Dr. Milligan, and consist of remains taken, as far us I cin judge, from three different deposits. In perusing the rransictions of your Society, I do not find that an attempt has jet been male to determine the relations of these beds to similiar deposits in Australia. Neither can I learn that a classifieation of the imbedded remins las been attempted. 'l'he following observations on the subject may, therefore, be of some little value.

Most of the members of the Society are probably aware that extensive tertiary deposits are found in Australia. They are, as far as known, restricted to the southern portions of the continent. From Carpentaria I have seen fossils from quarternary raised beaches, and also similar fossils from Perth in Western Australia. Generally the castern, northeru, and south-eastern portions of the continent are occupied by Palwozoic rocks, and this seems to be the case in Western Australid. The series of tertiary rocks in Southern Australia is very complete. Commencing in the west side of the Great Australian Biglit, they are but little interupted until the high land of Cape Otway is reahed. The only interruptions are, granite outcrops about Fowler's Bay, Port Lineoln, \&e., and the axis of the Flinder's range, which terminates at Cape Jervis. Upon the flanks of all these, up to a certain height, the tertiary rocks rest.

In some places, such as the Australian Bight, the beds are nearly 400 feet in thickness, which give almost at one glanee a conspectus of the whole of our tertiary formations. Between Warnuambool and Cape Otway there are equally perfect series, but not superimposed. It will very mueh elucidate what I have to say in this paper if I give an abstraet of Mr. Wilkinson's report on geology of the Cape Otway district. (See Reports of Geological Survey of Victoria.)

"The carbonaceous range which rises near Loutit Bay reaches 2,000 feet, 12 miles north of Apollo Bay, and whieh again falls to Moonlight Head, seems to have been an elevated portion of the sea bottom luring the deposition of the miocene strata. From position and the horizontal manner in which the upper beds of the series repose on the flinks of the range, I in inelined to believe they never wholly covered it. 'This formation occurs, at intervals, round the dividing range to 
Moonlight Head and thence to Cape Otway. Though not again seen to the east of the Cape for more than 40 miles, there can be little doubt that it was once continuous from Moonlight Head, to Point Addis. The cliff's on the coast near Spring Creek, 16 miles south of Geelong, expose a thickness of about 300 fect of miocene strata. The upper portion of the series is nearly 100 feet in thickness, consisting chiefly of yellow sandy limestone, the calcarious portion composed almost entirely of polyzoa and fragments of echini spines. The characteristic fossils are Cellepora Gambierensis, Busk, Hemipatagus Forbesii, Duncan, and the little Terebratula compta. Sow.-The middle series, which is about 150 feet thick, consists of soft, blue, brown, or yellow sandy clays. Bivalve shells are characteristic of these beds, the most common of which are Pectunculus laticostatus, Quoy. The fossils from the lower beds Professor M'Coy regards as belonging to the Upper Eocene.

"We find next Miocene occupying the base of the cliffs, about a mile and a half west of the Aire river. Here occurs a plant bed $17 \mathrm{ft}$. thick, containing fossil leaves. This bed consists of dark, almost black, argillaceous clay, with crystals of selenite, and the crevices filled with a yellow substance, determined to be basic sulphate of iron. This bed rests on miocene strata, with fossils soon covered over with more recent tertiary fossils, almost exclusively polyzoa, and a large Pecten (Hinnites Coriensis M'Coy?) Here a fossil seal's tooth was found (Phocodon Wilkinsoni $\mathrm{M}^{\circ} \mathrm{Coy}$ ?) which Professor $\mathrm{M}^{\prime} \mathrm{Coy}$ regarded as belonging to the same species as that found in the miocene of Malta."

I need not quote the abstract further. I only want to draw attention to the leading tertiary deposits found in Australia.

1. The polyzoan limestone, with Hemipatagus Forbesii and Cellepora Gambierensis. 2. Brown clays and sandstones, with Pecten laticostatus, \&c. 3. Plant beds, with leaves of species not belonging to the existing flora, highly ferruginous, and interstratified with mud, sand, lava, and volcanic ash.

The fossils in the Museum of the Society appear to me to be taken from beds belonging to the lower part of No. 1, and the upper part of No. 2. There are also plants taken from a bed similar to No. 3, and I have but little doubt that the plants recently described by Mr. Jolınson in your last year's Transactions will be found to belong to the same age. I now proceed to describe the fossils.

1. Cellepora Gambierensis Busk.-This fossil was named by Dr. Busk sixteen years ago, from specimens furnished by me; but as no diagnosis has ever been given, I proceed to describe the species myself. Polyzoary, large cylindrical branching 
irregularly, branches hollow, rarely enerusting, cells inflated, irregular, with large avicularium at each side of month, probably a socket for a vibraculum above.

2. Hemipatagus Forbesii Duncan.-Ann. Nat. Hist., vol. xiv., p. 165. - I regard the above two fossils as very characteristic of the upper (so-called Miocene or lower Pliocene beds of Australia.) Thev ale never found mingled with the lower fossils, except in intermediate beds, and then only sparingly, as in the present case.

3. Pecten laticostatus Quny.-This shell is still a common existing species in New Zealind, from whence I have received specimens; I believe from Dunediu or Invercargill, Middle Island.

4. Dentalium Kicksii Nyst.-This shell is described in Nyst's Coquilles, dc., des terrains tertiaries de la Belgique. As the work is scarcely accessible to Tasmanians, I give his diagnosis, D. testa tereti, subarcuata, longitudinaliter striata, striis irregulariter dispositis. He adds that this fossil is quite distinct from $D$. striatum Sow. of the London clay, though somewhat like $D$. grande and $D$. Bonce of Deshayes, Paris basin. The ends of all the species seen were constantly broken.

Dentalium long and narrow, finely streaked lengthwise. Striæ variable in number and position, and sometimes a vacant space or groove instead, sometimes irregularly placed between slightly elevated narrow and sharp ribs, prolonged along whole surface, and variable in number. Numerous transverse striæ indicating lines of growth.

6. Waldheimia.-This species was described by me in tho Transactions of the Adelaide Philosophical Society, and figured by that Society in 1866 . I find the synonym $W$. macropora $\mathrm{M}^{\circ} \mathrm{Coy}$ attributed to a specimen in the collections of the Victorian Geological Survey. It is very common in the Iurray beds, and in the Geelong miocene.

7. Rhynchonella lucida M'Coy.-I think the species found at Table Cape will be found identical with $R$. lucida of $\mathrm{M}^{\prime} \mathrm{Coy}$. It is common in the Geelong beds, and though probably now an extinct species, one like it occurs in the tertiaries of Spain in the glacial deposits, in the Norwich Crag (pliocene), and is still living in Australia: that is, R. psittacea Sowerby.

8. Cucculloa concamerata Reeve.--Very common in No. 2, Australia, and many specimens here. Living at present in the Mauritius seas, Nicobar, China. Figured by Sowerby, Gen. Char. Shells, Vol. 1, and in Woodward's manual.

9. Cyprœa eximia Sow.-This shell was described by Sowerby in Strzelecki's New South Wales, \&c., from a specimen said to have been found in a well at Franklin village, 130 feet below the surface. This, I presume, is near Laun- 
ceston, not Franklin, at the Huon, where the surface rock is volcanic tertiary dolerite. It would be very interesting to ascertain if the tertiary formation is found at great depths in the southern part of the continent, though a priori we might conclude it would be so. I append a translation of the diagnosis as the work is not generally accessible. Shell, ovately ventricose somewhat thickened, smooth polished, produced anteriorly and posteriorly, anterior prolongation the longest with two dorsal tubercles; posterior slightly reflexed; spire with two conspicuous whorls; aperture long, narrow, sinuous, canaliculate at each end; the posterior slightly ascending; external lip toothed in its interior margin; the posterior teeth small, anterior somewhat inconspicuous and interrupted; the internal lip with sharp transverse sulci on the inner margin, the interstices thicker and longer anteriorly, basal sides thickened at the extremities snd somewhat margined above. Mr. Sowerby adds:- "A fossil cowry of very remarkable form, bearing but a slight resemblance to any known species. It slightly resembles $C$. Scottii, but distinguished by its lengthened anterior and posterior canals, and by the two tubercles on the posterior dorsal part of the anterior canal, and by the very remarkable grooves or ribs of the inner edge of the inner lip.

I may add that the fossil is not uncommon in the Victoria Upper Tertiary, though it occurs in the lower beds as well, having a wide range.

10. Trigonia semiundulata MrCoy.-I take this name from the collections of the Geological Survey, Victoria, though no diagnosis has been published. The species is very common in the middle tertiaries of Victoria, and is easily recognised by half the ribs on the shell radiating, and half being concentric. In this respect it resembles a fossil British Oolite species, Trigonia costata.

Corbula sulcata, Lamarck.-This species is still living on the west coasti of Africa, as Prof. M'Coy (see Annals of Nat. Hist. for 1866) has pointed out. It is very characteristic of the Australian Lower Cainozoic. It is figured in Woodward's Manual, pl. 23, fig. 2 ; there are also excellent figures in Martini (Chemnitz) pl. 172, fig. 1668 to 1671 . Habitat of living species, Senegal, about lat. $16 \mathrm{~N}$.

Voluta Hannafordia, M'Coy, Ann. Nat. Hist., vol. XVIII., new series, p. 367.

Voluta antiscalaris, M[Coy, loc. cit.

Voluta macroptera, M'Coy, loc. cit.-Several specimens, but few old enough to manifest the peculiar extended outer lip. All these volutes are well known forms in the Australian L. Cainozoic. 
Cassidaria reticulospira M'Coy. Exhibition reports, 1866. Victoria.

Ancillaria mucronata. Sowerby Thes. Conch. pt. 63, pl. 211, f. 11.-This species exists in Tasmania, one of the very few forms surviving in the present series. There are trifling variations of character, but not, I bcliere, of specific value in the fossil form.

Dentalium lacterm? (Ditrupa?) Deshayes. Monograph of Dentalium. Living in the Indian seas. This is a doubtful identification. The fossil is very common, and may be a variety only. Another smooth Dentalium is living, and is found fossil in the Vienna basin. (D. entalis Linn.) but is very distinct from our species.

Turritella Tasmanica. n.s. (Diagnosis reserved for better specimens.)

Natica ovata Hutton, Catal. Ter. Mollusca of New Zealand, p. 9, No. 61.-This is a Pliocene fossil of New Zealand.

Natica Wintlei. n.s.

Triton Abbotti. n.s.

Fusus Roblini. n.s.

Terebra simplex. n.s.

Typhis MI'Coyi. n.s.

Solecurtus Legrandi. n.s.

Crasatella oblonga. n.s.

Crasatella aphrodina. n.s.

Lyonsia Agnewi. n.s.

Venus Allporti. n.s.

Besides fragments of a large Trochus, Haliotis, Corbis, Waldheimia, too imperfect for identification.

Polyzoa are few in number, as well as Foraminifera, $b_{1}: t$ this must not be wondered at, as the deposits are evidently transported from a distance. They are much broken and mingled with coarse fragments of quartz and ferruginous gravel, which seems to have comminuted the softer and smaller particles into fine mud. This mud bas even preserved the colour of the shells at times. Thus in the Solecurtus Legrandi, which is very closely allied to the existing but larger species in Brisbane, the pink colour of the shell is quite perceptible.

The corals of the deposit are not numerous, but of a larger size than any found in Australia. I have found three described species and two unknown hitherto. They are-

Placotrochus deltoideus. Duncan, Journal of Geological Society, vol. xxvi., p. 300 , et. seq.

Sphenotrocus excicus. Duncan, loc. cit.

Conotrochus MFCoyi. Duncan, loc. cit.

The above are well known Australian Lower Cainozoic forms. They are pedicellate corals and very cliaracteristic. I 
have found none of the eight described Australian I. C. Balanophyllia, which give such a peculiar facies to the Australian Tertiary coral fauna, since eight species of one genus, and that a rare one, is a remarkable palæontological fact. There is, however, a large cylindrical and much branched Balanophyllia, with a dense rugose epitheca and peculiar systems of cycles, which, I have no doubt, will prove most interesting to science when determined, as it will be, by our greatest living authority on corals, Prof. Duncan. There is also a coral of the Heliastræan type, which is also new in Australian palæontology. Both have been sent to Europe.

Amongst the Forminifera identified, we have Textularia pygmea, T. agglutinans, Cassidulina oblonga, Rosalina bertholetiana, and some few others, all evidence of deep water, say from 200 to 300 fathoms.

From the foregoing facts there can be little doubt that we have in Northern Tasmania a portion of the great tertiary formation which oceupies so much of the Southern Australian continent. From this we may conclude that Tasmania has shared the general upheaval, of which there is so inuch evidence as occurring in the continent during tertiary periods. Until the beds have been carefully examined it will not be competent for any one to hazard an opinion as to whether the upheaval in Tasmania has been greater or less than that observed in Australia, and whether now continuing or followed by subsidence. The position of the beds is in lungitude eastward of any deposits in Australia, and proves one more link to the union of these beds with the great tertiary formations of New Zealand. There can be but little doubt also that the tertiary leaf beds, which Mr. Johnson has lately described in so interesting a manner, form a part of this upper tertiary formation, and are connected with similar deposits near Cape Otway. A careful examination by a competent botanical Palæontologist would lead, no doubt, to the most interesting results.

As to the age of the beds, I cannot do better than append the published opinion of Dr. Duncan, one of the secretaries of the London Geological Society, whose lindness and industry in attending to all my communications on the subject of Australian tertiary fossils have led to the great progress which Australian Palæontology has lately made. I may add that to him, Professor Mr'Coy, Professor Etheridge, and Mr. Moore, F.G.S., we owe nearly all we know of the fossils of Australia.

In the Quart. Journ. Geo. Soc., Vol. 26 p. 313, he says that the corals of the Australian tertiaries are very characteristic. They were not reef builders, but forms which tenanted the sea bottom from low spring tide, much to the depth where polyzoa 
abound. The species of the different beds have so great a general resemblance, that they do not offer evidence of any biological changes during the deposition of the whole. He points out that it is inconsistent with the rules of geological classification to subdivide the series ivto Oligocene, Lower, Middle, Upper Miocene and Pliocene, which in Europe have very distinct fauna. The percentage system cannot yet be applied to Australian beds, as the Mollusea existing are so little known, and a comparison of the corals would make them older than the evidence of the physical geology warrants. There was evidently in these periods much disturbance and alteration of currents in the sea bottom, formed of Silurian rocks, basalts, and carbonaceous sandstones; conglomerates, pebbly sandstones, clays and clayey sandstones alteruated under different conditions during a vast period of subsidence connected with the outpouring of trap rocks, covering littoral deposits and the gradually denuded rocks. The leaf beds show temporary upheavals. The relatious of the leaf beds, clays, gJpsum and basic sulphate of iron, so frequently seen in Europe, are repeated in Australia. The chemical decomposition of these beds accounts for their contortion. No other disturbance is manifested in Australia in which the beds contrast with the changes to which the tertiaries of the West Indies, Europe and Sindh have been subjected.

Dr. Duncan thinks that during the long duration of time during which Australia was a sea, there was open water to the north, with reefs in the lava district and corresponding formation, opening into what is now the Mediterranean, and the Sahara to the north-west. The Indian peninsula, and the area now occupied by the Himalayas, and stretching far away to the east, were not a part of a great continent. The greater part of the American continent was submerged, and the Carribean Sea was a coral sea. He then suggests that the bulk of land must have been to the extreme north and south of the globe. Australia and New Zealand, he adds, Trere bounded on the north by a coral sea, and on the south by a deep sea, as now. In this way he accounts for the persistence of earlier types in Australia, and its perfect disconnection from Europe in its present and existing fauna and flora. For though corals are known to have an enormous range, very few are common to Australian and European tertiaries. "The absence of any littoral connexion between Australia and the points to the north in the tertiary period, and the remoteness of the south of its area from any great centres of frequent terrestrial oscillations, may explain the persistence of type." This persistence was infinitely less in Europe on account of the more frequent changes in its physi- 
eal geology. The distinct and comparatively quiet area of Australia was hence tenanted by the same species, whilst vast biological and geological changes took place in the Europear area, formerly considered the type by which all others would be compared. He adds that the extinction of Australian volcanoes, and the change in its coraI flora, were grand phenomena, which he also regards as contemporaneous with the upheaval of the Alps, Himalayas, New Zealand, and the closure of the Isthmus of Panama. He points out the enormous denudation of the Australian area from the thickness and extent of unfossiliferous deposits which cover the marine. During the glacial period of Europe, he supposes that subaerial denudation went on. The gold drifts, sandy ferruginous clays, coarse pebble grits, and hard ironstone, cements and conglomerates with the lava plaius north of Cape Otway, are of this age, and younger than the polyzoic limestones.

To all these conclusions I would readily subscribe, except to that portion which supposes Northern Australia completely submerged, and no land to have been north of the tertiary sea. The following are facts on the subject:-1. The tertiary marine fossiliterous beds thin out rapidly as they are followed north. In the south-east portion of the continent this occurs in a few miles, and in any case they are not known further than 30 deg. S. lat. 2. The enormous development of upper secondary beds in the north of the continent, and their complete absence from the south. This seems to show that North Australia has escaped the general tertiary denudation, which would not have been so had these beds been submerged. Besides, they are very soft in character, and so horizontal, that they do not appear to have suffered any disturbance in tertiary periods. Thirdly, the only tertiary rocks which are found in North Australia appear to be either subaerial or lacustrine. Last of all, the physical geology of the tertiary deposits serve to show that the sea encroached upon the present area of Australia in a great horse shoe form, and that the contour of the continent gives a good general idea of the shape of the great tertiary sea basin. Add to this that the flora and fauna of the land seem to be a connecting link with the secondary fauna and flora of Europe, which is very easily understood, if we suppose a part of the Australian continent to have been undisturbed. South Western Australia possesses these features in the most marked way, and this is the portion of the land, too, where the physical geology is against the supposition of any submersion.*

* Dr. Hooker says the Australian orders (abundant there and rare elsewhere) are very unequally distributed in Australia. There is a greater specific difference between S.E. and S.W. Australia than between Australia 
In conclusion, Dr. Duncan suggests that the word "Tertiury" should only be used relatively in Australian geology, but all ahore the carbonaceous sandstones should be called Cainozoic; but this, I presume, is for Victoria and South Austrilia, as there is a full series of intermediate Mesozoic rocks in Queensland, and probably Western Australia. He would refer all below the Mount Gambier limestones to Lower Cainozoic. That deposit he would call Middle Cainozoic, and all above Upper Cainozoic. The Table Cape beds should therefore be called Lower Cainozoic. $\mathrm{He}$ says that the tertiaries of New Zealand should be studied in relation to those of Australia, and he regards the polyzoic limestones of the North Island as the equivalents of the Mount Gambier Middle Cainozoic. "At present," he says, "all that can be arrived at, concerning the relative position of the Australian tertiaries, is that they were formed on a sea bottom of the oldest rocks in increasingly deep water, during a period when the denudation of the neighbouring coast line to the east and north-east was rapid. They were very distinct from the reef area of the period, and the physical conditions of such an area were never present during the deposition of these beds, which have a facies characteristic of all the European marine tertiary deposits above the nummulitic. They were subjected to frequent volcanic outbursts, which covered large areas with basalt and ash, and they were covered after the general upheaval of the centre of Australia with lacustrine, dune, river and torrent deposits, whose depth testifies to the enormous denudation of the older rocks. The condition of the high land on the extreme east and west of Australia was probably that of dry land during the whole Cainozoic period, and these districts probably bounded the tertiary sea."

The italics are my own, as I wish to indicate those conclusions which are borne out by all that Australian geology has taught me in many years' investigations.

\section{DIAGNOSIS OF NEW SPECIES.}

Fossills frodi Table CAPE.

(Note all measurements in French millimetres.)

Terebra Smplex, n.s. T. testa fusiformi-turrita, acuminata, striis numerosis, flexuosis, tenuibus, transversalibus : anfractibus planulatis superné, sutura vix impressa; apertura angustata; columella contorta, recurva, basi emarginata, labro angusto.

Anf. 13. Long $50 \mathrm{mil}$. Lat $11 \mathrm{mil}$. T. shell terete, smooth, without grooves, finely wrinkled, with undulating transverse

and the rest of the globe, and the most marked characteristics of the flora are concentrated at that point, which is geographically most remote from any other portion of the globe.-Flora of Tasmania. The Introd. : xxxiii. 
lines, suture overlapping, aperture narrow, columella arched, twisted and recurved at the base, outer lip sharp.

A very simple shell with smooth whorls. The specimen in the museum has mottled brown spots at the suture, which seem very much like the traces of former coloring. There is no described species at all like it.

Typuis M'Coyr,u.s., T. testa ovato-ollonga, fusiformi-lavigata, quadrifariam varicosa; varicilus spinosis (ult. anf. spin. 5); anfractibus convexiusculis, tubiferis ; ultimo anfiracto canali longo, angusto, arcuato, claneso, terminato; apertura ovata,integra; labro incrassato, varicibus 2 et 3 canali recurvo terminatis. Long 38 mill. Lat. 22. Anfr. 7.

T. shell ovately oblong, fusiform, smcoth, with four spinose varices in each whorl $(5$ spines on each of the varices of the last whorl) whorls convex, tubiferous, last whorl terminating in a long narrow recurved closed canal, mouth ovate entire, with a thickened lip, second and third varices uniting into a recurved canal.

This fossil is somewhat near the Murex tubifer Brug. of the European eocene at least as far as Nyst's figures and descriptions guide. Brugière says (Encycl. Method.) that the species is living in Ceylon, but no such shell is figured in Reeve or Sowerby. The nearest congener in Southern deposits is the $T$. Zealendica, Hutton, of the Wanganui Pliocene, but it is very distinct.

Fusus Roblini, n. s. F. testa contorta, fusiformi, anfi. tenuiter longitudinaliter sulcatis et striatis, superne ad angulum plicato-tuberculatis, tuber., acutis, subdistantibus (in ult. anfr. 13) apertura elongato-pyriformi, superné angulata, columella contorta, canali recurvo. Long. 75. Lat. 37. Anfr. 7.

F. shell twisted, fusiform; whorls finely spirally sulcate and striate, whorls seven, with a row of sub-distant somewhat sharp tubercles on the outer sloping margin, which is there angulated; tubercles 13 in body whorl, aperture elongately pyriform, columella twisted, canal recurved. I have named this species which is very distinct, after Mr. Thos. Roblin, the industrious curator of the Society's Museum, whose ready and prompt assistance has been of the greatest service to scientific investigators.

Fusus gracillmus, n.s. F. testa lanceolato-fusiformi, gracillima, solidiuscula, transversim striata et sulcata; striis subtilibus,confertis,nodulosis ; sulcis peculiariter plano-excavatis ; longitudinaliter costatis; costis brevibus interruptis; anfractibus convexis; apertura angusto-ovata, superne angulata cauda pralonga, aperta, gracili terminato. Anf. 8. Lon. 33. Lat. 12.

F. shell, lanceolately-fusiform, most graceful, somewhat solid, transversely striate and sulcate; striæ. very fine, close 
and nodulose; sulci in peculiar flat grooves; ribbed lengthwise, with short intermpted costæ, whoris convex, angulate above, termiuated by a long open @raceful canal.

'This beautiful fossil is very near to Fusus acris (Reeve and Adams) of the China seas, and Fi. longirostris of the Vienna basin. If many of each species were put together I have no doubt gradations from one to another would readily be traced. They may be identical. Many miocene forms exist still in China, and some of the European types closely approximate to those living in the Eastern seas.

Natica Wintlei,11.s. N. testa canaliculato-umbilicata, obliqué globosa, subtus concara, solidiuscula; spira clongata, apice acuta ; anfractibus rotundatis, tenuissime striatis ; apertura lunari-ovata, callositate pas'a, columnari umbilicum, vix intrante. Anfr. 5. Long. 25. Lat. 19.

N. shell eanaliculately-umbilicate, obliquely globose, concare beneath, rather solid, spire elongate, whorls rounded, apex acute, very delicately striate, ajerture lunately-ovate, columuar callosity small and only slightly entering the umbilicus.

This fossil I have dedicated to Mrr. Wintle, who has long and industriously worked amid the Tasmanian rocks.

Natica Polita, n.s., N. testa parva, nitida, ventricosa, sulglobcsa, umbilicata, fragili, levigata, transversim substriata, long. lincis obsoletis fasciata; anfractibus 5, subglobosis, ad sutur. profunde canaliculatis ; apertura ovato-semilunari, margine sinistro reflexo, dextro tenui acuto. Anf. 5. Long. 13. Lat. 11.

N. shell small, shining ventricosely sub-globose, umbilicate, fragile, smooth or transversely substriate, banded with obsolete lines, suture profoundly canaliculate, aperture ovately semilunar, left margin reflexed; right thin acute.

This shell is very different from any existing or extinct species, coming nearer to some European Eocene fossil forms than any other.

CYPR.FA ARCHERI n.s. C. testa ovato oblonga, lavigata, medio inflata, utrinque sub-attenueta, antice subrostrata, postice attenuata, utriusque rmarginata, spira vis cooperta: apertura basim rersus latiore; dentibus partis, numerosis, subaequalibus, long. 23, lat. 14.

C. shell orately oblong, smooth, inflated, somewhat attenuato at each end, slightly rostrate above, attenuate below, cmarginate at both ends, spire not quite covered, aperture broader towards the base and furnished on both lips with numerous sub-equal teeth.

This fossil is not very different from $C$. sanguinolenta Gmelin (in Lin. Syst. Nat., p. 3406, N. 38) which is found in the miocene faluns of Touraine and in the Vienna basin. Compared with Haidinger's figures, the difference is slight, 
but the actual fossils side by side are very different. I have named this after my esteemed friend, Mr. W. H. Archer, the learned Victorian statist, whose labours in every branch of science are well known.

Triton Aввоті, n.s., T. testa elongata, acuta, turrita, varicibus tribus,longitud. striatis, striis plus minusve interruptis vel nodosis, (ad lab. et canal. regulariter alternatis); anfractilus irregulariter convolutis, globosis, angulis tuberculisque biseriatim armatis; ultim. anfiact. canali longo, arcuato, recurvo, aperto, terminato; apertura ovata integra, labro incrassato, intus denticulato. Long. 50. Lat. 30.

Triton shell elongate acute, turrited, with three varices, spire-twisted, whorls globose, armed with two sharp angles, on which are a series of sharp tubercles, the upper larger, 12 in first whorl, the lower becoming very small and obsolete at the outer lip, shell long. striate, the striæ becoming obsolete or dotted, at the mouth on alternate lines; last whorl termin nating by a long, open, arched, and recurved canal, aperture entire, outer lip denticulate interiorly.

This shell I have dedicated to Mr. F. Abbott, the curator of the Royal Society's gardens. It is common. As in other shells in these beds, there are distinct traces of color on the shell, which has a bluish ground, with brownish square spots in zigzag lines.

Crassatella aphrodina, n.s. C. testa trigono-ovata, olliqua, tumida, crassa, tenuiter striata et sulcata, umbonibus sulcatis angustis ; lunula impressa, latere postico subangulato, productiore. Long. 5:. Lat. 44.

C. shell ovately trigonal, oblique, solid, faintly striate and sulcate, umbones sharp, with more distinct sulci, lunule impressed, posterior side subangulate and prolonged.

VolUTA WELDII, n.s., V. testaovato-conica, ventricosa, solida, long. tenuissime striata, spira conica, mammillata; anfractibus ad angulum tuberculis acutis coronatis (tuber. ultim. anfi. 9); apertura angusta; labro simplici, crassiusculo, superne emarginato; columella arcuata, medio 4-plicata; callo magno. Long. 41. Lat. 22. Anf. 8.

$\mathrm{V}$. shell ovately conical, ventricose, solid, long. finely striate; spire conical, mammillate; whorls with sharp-edged tubercles at the angle (last whorl 9, and coming towards the middle of the whorl near the aperture), aperture narrow, lip thickened, simple, emarginate above, columnella somewhat curved with four plaits in the middle, enamel, widely spread over the lower part of the shell.

This shell is very near Nyst's Voluta depressa Lam. (See Nyst Recherches sur les coq. foss de Hoesselt et de Kleyn Spauwen. p. 37, no. 29, et pl. iv., fig. 99.) It is a miocene 
form conmon at Bordeaux. Our shell is however thicker, and the four plaits on the columella show its distinctness, though it adds one more to the many instances of mimetism, that is to say, forms, which seem closely approximate to types in contemporary European beds. This is especially seen in the volutes, which Professor $\mathrm{M}^{\circ} \mathrm{Coy}$ was the first to point out in describing Toluta antiscalaris. The only living form at all near it is V. flavicans Gmelin, which is Australian.

LYONSIA A GNEwi n.s. L.testa ovato-transversa, inœquilateralis, convexa, concontrice striata et sulcata; latere postico attcnuatorotundato, antico oblique producto, latiore, aperte anticc et postice hiante. Long. 82. Lat. 1. 44.

L. shell transversely orate, inequilateral, somewhat solid, convex concentrically striate and sulcate,posteriorly attenuately rounded, exterior obliquely produced, broader, gaping at both ends.

This fossil I have dedicated to Dr. Agnew, secretary of the Society, to whose indefatigable labours the flourishing state of the Society is owing.

Solecurtus Legrandi n.s. S. testa polita, oblonga, incquilateralis, latere postico elongato, utrimque subtruncato, hiante, medio et postice oblique sulcata, sulcis prope marginem dorsalem retrosim angulatis. Long. 44. Lat. 19.

S. shell polished oblong inequilateral, prolonged posteriorly, subtruncate at both ends, gaping, obliquely grooved, grooves angularly turned back near the dorsal margiu and radiating from the umbones towards the margin.

This fossil is very near to the Solecurtus Australis of Dunker, which now inhabits N. Australia; it is, however, smaller. Traces of the pink color of the shell are plainly visible. I have dedicated the species to Mr. W. Legrand, of Hobart Town, the learned conchologist, whose most painstaling enquiries into our living molluscan fauna have resulted in his monograph of Tasmanian land shells, besides many additions to the marine fauna. I have also thankfully to acknowledge the assistance I have received from him in preparing this list.

Crassatella oblonga, n.s. C. testa ovato-transversa, incequilateralis, crassissima,convexa,transversim sulcata,sulcis posterioribus tenuibus, latere postico angulato, sinuato. Long. 93. Lat. 67.

C. ovato trigonal, inequilateral, very convex, obliquely truncate behind, closely concentrically ribbed, the ribs becoming fine striæ on the posterior flattened portion, hinge large thick, lunule impressed, with a distinct ridge from the umbo to the base of the truncated flattened posterior margin.

This shell which is very distinct from any existing species, and very large, is somewhat similar in form to $C$. attenuati, 
Hutton of the Lower Miocene, New Zealand. It is apparently rare.

Vends Aliforti n.s., $V$. testa ovata, obliqua, anterius angulata, subdepressa, tenuissime striata, albida, lamellis transversis, subdistantibus, appendiculatis. Long., 29. Lat., 19.

V. shell ovate, oblique anteriorly, angulate, subdepressed, slenderly striate, white, with transverse subdistant appendiculate lamellæ.

This shell which very closely resembles $V$. lamellata var. subdepressa of Lamarck (1st edit. Hist. des Moll. Vol. 1, p. 349). It is, howerer, a smaller shell and more irregular in the lamella and not striate on the anterior side of the same. There is but one specimen of this fossil in the Museum, and that very much damaged. It is possible that a larger suite of specimens may show it to be identical with the living form whose habitat is Tasmana. 